\title{
Prolidase Deficiency
}

National Cancer Institute

\section{Source}

National Cancer Institute. Prolidase Deficiency. NCI Thesaurus. Code C85029.

A rare autosomal recessive inherited inborn error of metabolism caused by mutations in the PEPD gene. Signs and symptoms include facial abnormalities, mental retardation, skin ulcers, susceptibility to infections, and skeletal abnormalities. 